\title{
Dinamika salinitas daerah penangkapan ikan di sekitar muara Sungai Malalayang, Teluk Manado, pada saat spring tide
}

\author{
Dinamics of salinity in the fishing ground off Malalayang River mouth, Manado Bay, \\ at spring tide \\ WAHYU D. SEPTIANI*, PATRICE N.I. KALANGI dan ALFRET LUASUNAUNG \\ Program Studi Pemanfaatan Sumberdaya Perikanan, Fakultas Perikanan dan Ilmu Kelautan, \\ Universitas Sam Ratulangi, Manado 95115
}

\begin{abstract}
Estuary is part of a coastal area which has high biology productivity. In this area, sea water and fresh water are mixed. River flow and sea water movement due to tides affect the salinity. This research was done in November 2014 based on survey method. The result showed that the distribution of salinity off Malalayang River mouth changed with tidal current. During ebb tides, river discharges flow to the right while during flood tides the discharges flow to the left from the river mouth.
\end{abstract}

Keywords: salinity, tides, estuary, Malalayang River, Manado Bay

\begin{abstract}
ABSTRAK
Muara merupakan satu bagian dari wilayah pesisir yang mempunyai tingkat kesuburan yang tinggi. Pada wilayah ini terjadi percampuran antara massa air laut dengan massa air tawar dari daratan. Adanya air tawar yang bergerak terus menerus dari hulu dan adanya proses pergerakan air laut akibat pasang-surut mengakibatkan terjadinya perubahan salinitas. Penelitian ini dilakukan pada bulan November 2014 dengan metode survey. Hasil penelitian menunjukkan sebaran salinitas di perairan depan muara Sungai Malalayang mengikuti pergerakan arus pengaruh pasang surut. Ketika permukaan laut sedang surut, maka air sungai mengalir ke arah kanan dari muara sungai, sedangkan jika permukaan air laut sedang pasang maka air mengalir ke sebelah kiri dari sungai.
\end{abstract}

Kata-kata kunci: salinitas, pasang surut, muara, Sungai Malalayang, Teluk Manado

\section{PENDAHULUAN}

Perairan sekitar muara Sungai Malalayang merupakan daerah yang potensial bagi pembangunan sosial dan ekonomi masyarakat sekitar. Kawasan ini telah dimanfaatkan untuk berbagai kegiatan, di antaranya untuk kegiatan perikanan dan rekreasi.

Estuari merupakan bagian perairan semi tertutup yang berhubungan langsung dengan laut terbuka serta tercampur dengan air tawar dari daratan (Chester, 1993). Odum (1971) lebih spesifik menyebutkan definisi estuari sebagai mulut sungai (muara) tempat terjadinya percampuran antara air asin dan air tawar sebagai hasil

\footnotetext{
* Penulis untuk penyuratan; email: wahyudseptiani@gmail.com
}

dari gaya pasut.Pada wilayah ini terjadi percampuran antara massa air laut dengan massa air tawar dari daratan sehingga estuari dapat dikatakan memiliki keunikan tersendiri. Adanya air tawar yang bergerak terus menerus dari hulu dan adanya proses pergerakan air laut akibat pasang-surut (pasut) mengakibatkan terjadinya perubahan salinitas.Menurut Kalangi (2008), struktur salinitas pada perairan dekat muara sungai yang berdebit rendah tidak konsisten, hal ini di sebabkan oleh energi yang dihasilkan oleh air sungai tersebut tidak mampu mengatasi energi dinamis lautan; dan percampuran akan terjadi di mulut sungai. Dalam pedoman penulisan jurnal terbitan Elsevier (2014),salinitas harus dilaporkan sebagai angka tanpa simbol atau indikator, maka tidak benar bila menambahkan huruf PSU (Practical Salinity Unit). 
Estuari merupakan daerah yang produktif yang setara dengan hutan hujan tropik, karena perannya sebagai sumber zat hara serta sebagai tempat terjadinya fluktuasi permukaan air akibat pasut. Tetapi, daerah estuari juga dapat menjadi "pollutant trap" atau perangkap bahan pencemar karena sedimen dapat mengabsorbsi logam-logam berat (Supriharyono, 2000).

Salinitas mempunyai pengaruh penting pada sistem ekologi laut. Distribusi biota akuatik sangat erat hubungannya dengan salinitas karena ada beberapa jenis biota yang tahan dengan perubahan nilai salinitas yang besar yang disebut stenohaline. Tetapi ada pula organisme yang dapat bertahan dengan perubahan salinitas yang besar yang disebut euryhaline contohnya bandeng, kakap dan nila merah.

Perairan di depan Sungai Malalayang sering digunakan oleh masyarakat sekitar sebagai daerah penangkapan. Adapun jenis ikan yang biasa ditangkap adalah ikan kerapu dan kakap. Lokasi ini juga banyak dimanfaatkan sebagai tempat rekreasi memancing oleh masyarakat.

Supriadi (2001) menyatakan bahwa selain pasut, musim juga dapat menyebabkan peru-bahan salinitas di daerah estuari. Pada musim kemarau, volume air sungai akan berkurang sehingga menyebabkan air laut dapat masuk ke arah hulu, hingga menyebabkan salinitas di wilayah tersebut meningkat. Sebaliknya bila musim hujan, air tawar yang mengalir dari arah hilir meningkat sehingga salinitas di wilayah estuari menjadi turun/rendah. Neumann dan Pierson (1966) menyatakan bahwa rendahnya salinitas pada perairan estuari atau muara disebabkan karena adanya pengenceran pada saat musim hujan. Menurut Kalangi dkk. (2012), ketebalan lapisan air sungai di laut dapat diduga berdasarkan data curah hujan dan ketebalan air tawar di laut akan lebih tebal dibandingkan pada hari-hari tidak hujan.

\section{METODE PENELITIAN}

Penelitian dilakukan di perairan muara Sungai Malalayang, Kecamatan Malalayang I Timur Kota Manado. Pengumpulan data dilakukan pada tanggal 07 dan 21 November 2014. Penelitian ini dilakukan dengan menggunakan metode survei. Kegiatan pengumpulan data meliputi pengukuran pasut, debit air sungai dan salinitas. Data dari hasil pengukuran salinitas kemudian diolah menggu- nakan aplikasi Matlab untuk mendapatkan grafik sebaran salinitas di perairan depan muara Sungai Malalayang. Panjang pengaruh air sungai diduga dengan menggunakan rumus (Geyer dkk, 2000):

$$
L=\frac{u}{f},
$$

dengan $u$ adalah kecepatan air sungai di muara dan $f$ adalah frekuensi Coriolis $\left(3,72 \times 10^{-6} \mathrm{~s}^{-1}\right)$. Frekuensi Coriolis dapat dihitung dengan $2 \Omega \sin \varnothing$, dimana $\Omega$ adalah sudut percepatan rotasi bumi yang besarannya $2 \pi$ radian dalam satu hari atau $7.29 \times 10-5$ rad s-1 (satu hari $=23$ jam 56 menit 4 detik $=86.164$ detik yang merupakan waktu yang dibutuhkan oleh bumi untuk berputar pada porosnya) (Pond dan pickard, 1983).

Survei salinitas dilakukan pada 5 transek (yang diberi label alfabet) dan pada masing-masing transek terdapat empat stasiun (yang diberi label numerik). Secara keseluruhan pengambilan sampel air laut dilakukan pada 20 stasiun (A1, A2, A3, $\mathrm{A} 4, \ldots, \mathrm{E} 3$ dan E4), posisi stasiun didapatkan dengan menggunakan GPS.

\section{HASIL DAN PEMBAHASAN}

\section{Pasang surut dan waktu pengambilan sampel}

Tinggi pasut pada tanggal 7 November 2014 adalah 2,06 $\mathrm{m}$ dengan pasang tertinggi terjadi pada pukul 19:00 dengan ketinggian pasut yaitu 2,26 m dan surut terendah terjadi pada pukul 12:00 dengan ketinggian $0,20 \mathrm{~m}$. Pada tanggal 21 November 2014 tinggi pasut sekitar 2,01 m. Pasang tertinggi terjadi pada pukul 17:00 yaitu 2,32 m dan surut terendah terjadi pada pukul 10:00 dengan ketinggian pasut sekitar $0,31 \mathrm{~m}$.

\section{Pengaruh debit sungai}

Gambar 3 dan 4 menunjukkan adanya cekungan kontur di depan mulut sungai. Hal ini diakibatkan oleh kecepatan dan debit air sungai yang masuk ke laut. Pada tanggal 7 November, ketika permukaan laut surut debit air tawar yang mengalir masuk kelaut (Q) adalah $2.740 \mathrm{~m}^{3}$ dengan kecepatan arus sungai di bagian permukaan $(u)$ adalah $0,2075 \mathrm{~m} / \mathrm{s}$. Panjang pengaruh air sungai (L) di laut dapat mencapai 55.761,43 $\mathrm{m}^{3}$ dan pada tanggal 21 November 2014, $\mathrm{Q}=2.800 \mathrm{~m}^{3}$ dan $u=0,225 \mathrm{~m} / \mathrm{s}$ dan $\mathrm{L}=60.464,2 \mathrm{~m}$. Nilai $\mathrm{L}$ dapat terjadi karena pengaruh arus dan gesekan dianggap tidak ada. 


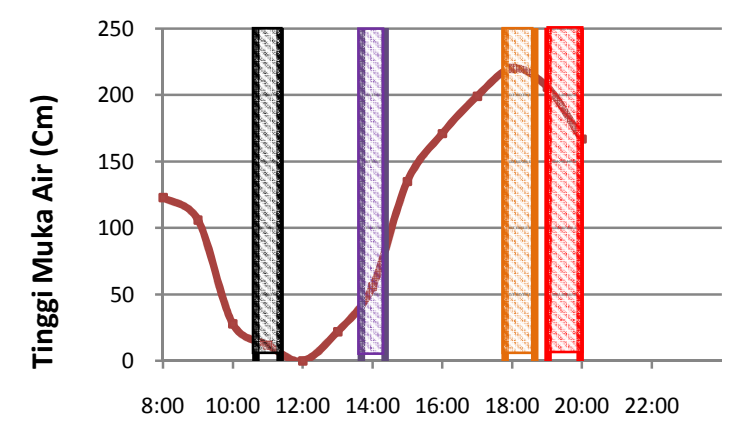

Jam

7 November 2014

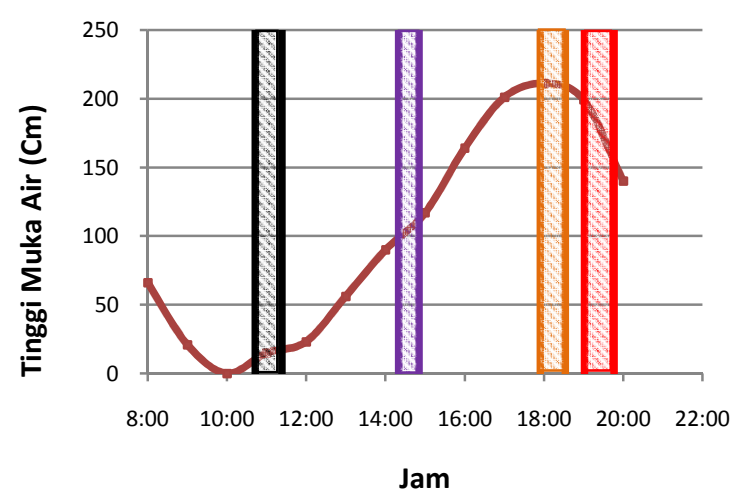

21 November 2014

Gambar 1. Tinggi pasut dan waktu pengambilan sampel: 0 pengambilan pertama, ketiga, 2 Pengambilan keempat

\section{Sebaran salinitas berdasarkan kondisi pasut}

Pada saat air sedang bergerak surut, air tawar yang keluar dari sungai bergerak ke arah kanan dari mulut sungai. Hal ini disebabkan oleh adanya arus bergerak sejajar garis pantai yang mendorong air tawar yang masuk ke laut. Hal ini sesuai dengan Kamat dkk. (2014) yang menyatakan bahwa pada saat periode permukaan laut surut arus cenderung ke arah timur dengan kecepatan yang relatif tinggi. Rampengan (2009) menyatakan pola pergerakan arus di Teluk Manado, fokus utamanya berada pada bagian tengah, sedangkan pada ruang lainnya hanya merupakan akibat dari kejadian pada ruang utama tersebut.

Saat permukaan laut bergerak pasang arus berbalik sehingga air tawar yang keluar dari sungai didorong dari sebelah kanan sehingga air laut yang bersalinitas rendah bergerak ke sebelah kiri dari mulut sungai, kontur terbentuk dengan cembungan berada tepat di depan muara. Ketika permukaan laut telah pasang distribusi salinitas menjadi kebalikan dari saat surut. Pada saat pasang salinitas telah berada di sebelah kiri dari muara; dan ketika akan bergerak surut, air laut yang bersalinitas rendah bergerak ke arah kanan.

\section{Distribusi salinitas berdasarkan umur pasut}

Kontur salinitas 30 pada saat surut spring tide berkisar antara 150-200 m dari garis pantai. Hal ini dikarenakan pada saat spring tide, terjadi surut terandah. Ketika surut terjadi air sungai yang memiliki salinitas rendah mengalir kearah laut dengan kecepatan yang lebih tinggi sehingga dapat bergerak hingga jarak yang lebih jauh ke tengah laut. 
W.D. Septiani dkk.

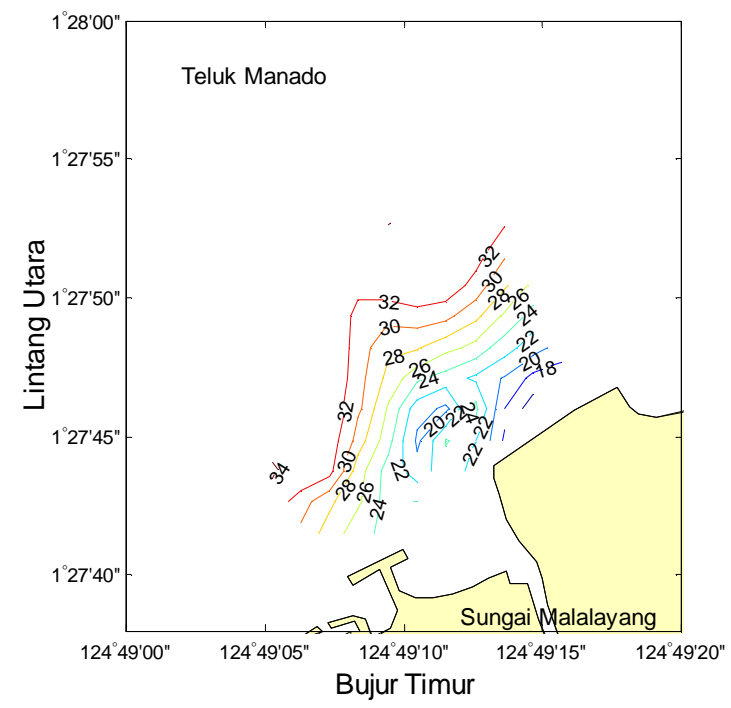

(a)

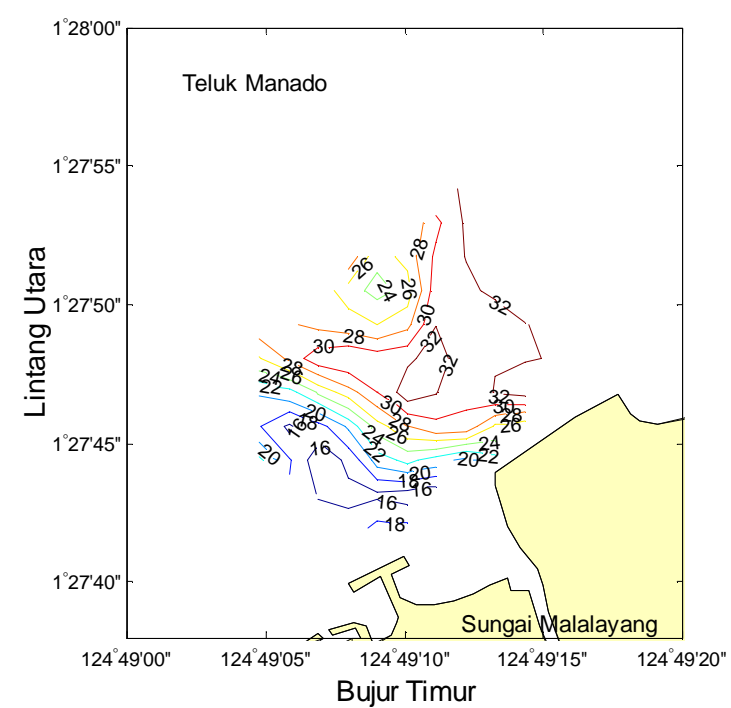

(c)

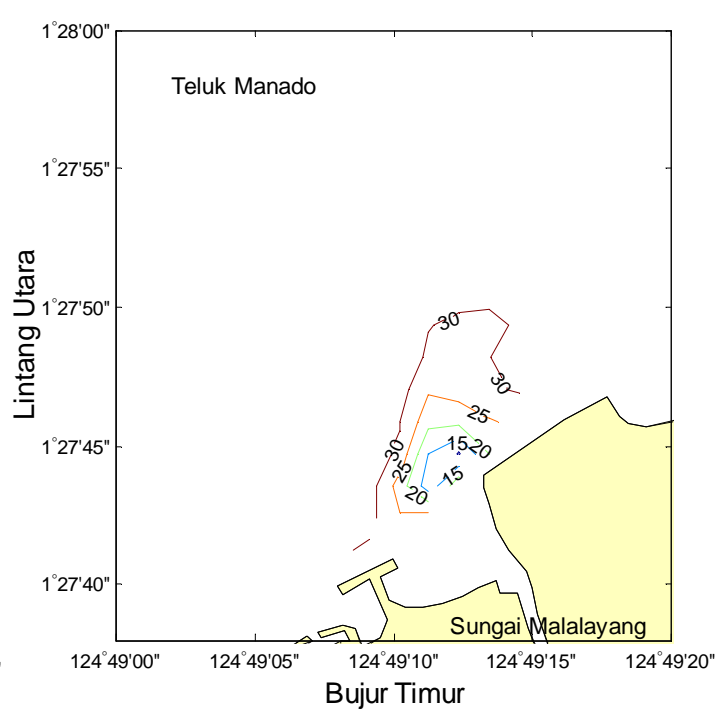

(b)

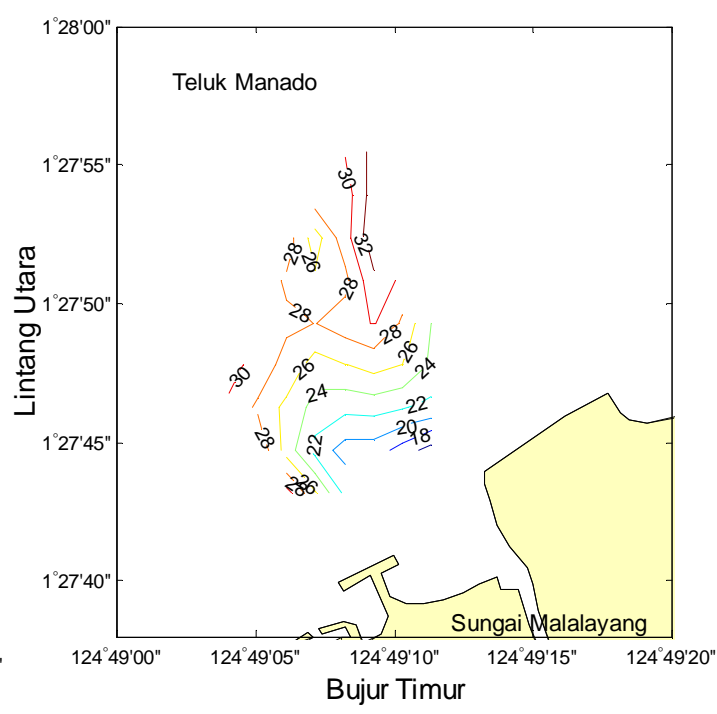

(d)

Gambar 2. Sebaran salinitas permukaan 7 November 2014: (a) saat air laut surut, (b) saat air laut bergerak pasang, (c) saat air laut pasang, dan (d) saat air laut bergerak surut 


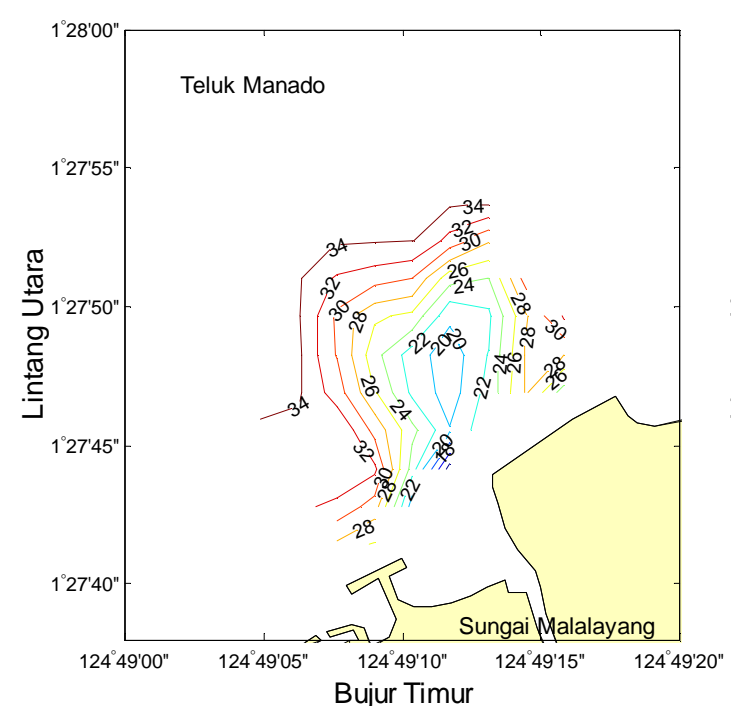

(a)

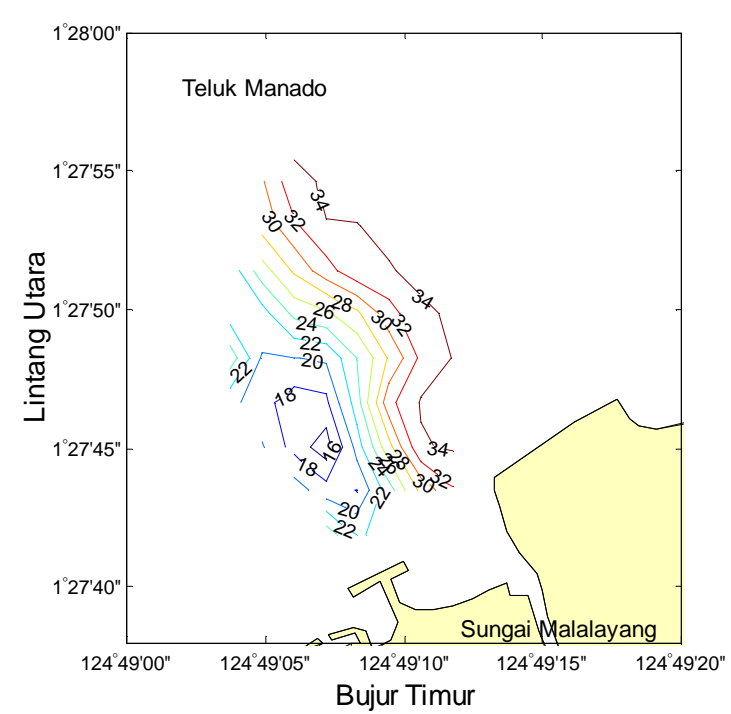

(c)

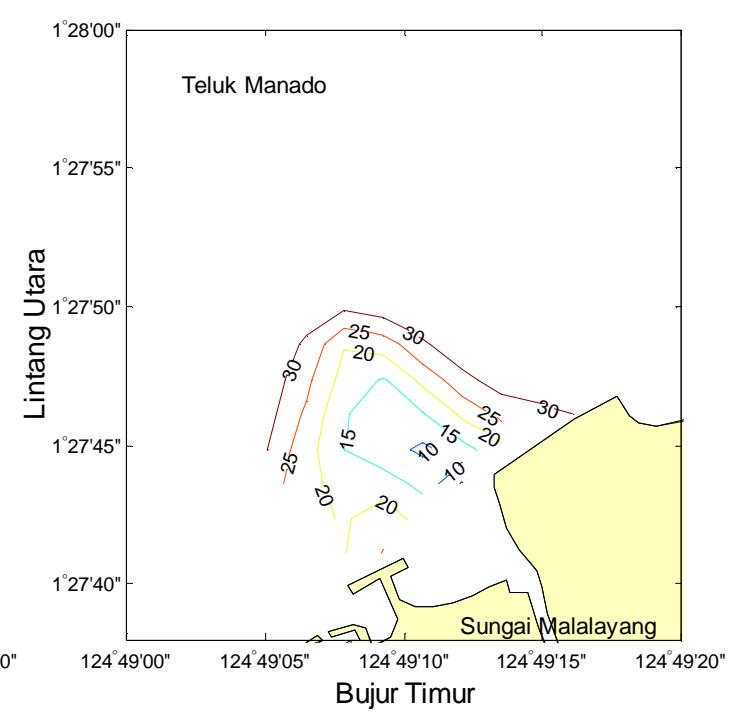

(b)

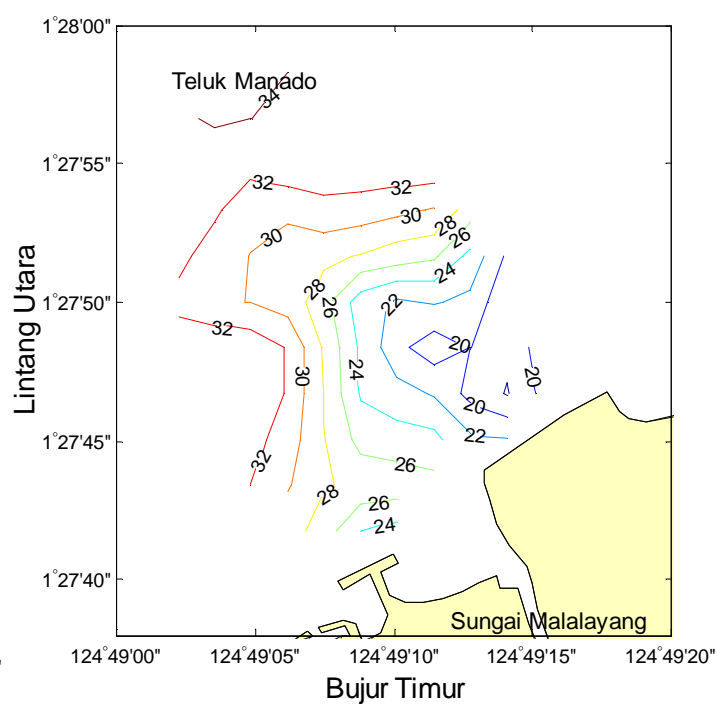

(d)

Gambar 3. Sebaran salinitas permukaan 21 November 2014: (a) saat air laut surut, (b) saat air laut bergerak pasang, (c) saat air laut pasang, dan (d) saat air laut bergerak surut 


\section{KESIMPULAN}

Dinamika salinitas di perairan depan muara Sungai Malalayang dipengaruhi oleh arus pasang surut, tinggi pasang surut dan debit sungai. Hasil pengukuran salinitas pada perairan depan muara Sungai Malalayang memperlihatkan bahwa sebaran salinitas mengikuti pergerakan arus yang terjadi karena adanya pengaruh pasang surut. Ketika permukaan laut sedang surut, maka air tawar yang masuk ke laut didorong ke arah kanan dari muara sungai, sedangkan jika permukaan air laut sedang pasang maka air tawar yang masuk ke laut akan didorong ke sebelah kiri dari sungai.

Pada saat surut penampang sungai menyempit dan mengakibatkan air sungai yang bersalinitas rendah mengalir ke arah laut dengan kecepatan yang lebih tinggi sehingga dapat mencapai jarak yang lebih jauh ke tengah laut. Selanjutnya, pada saat debit air sungai tinggi, massa air yang bersalinitas rendah menyebar sampai jauh ke laut.

\section{DAFTAR PUSTAKA}

Chester, R. 1993. Marine Geochemistry. Unwin Hyman Ltd., London.
Elsevier. 2014. Guide for Authors, Estuarine Costal and Shelf Science. http://www.elsevier.com/journals/estuarinecoastal-and-shelf-science/0272-7714/guide-forauthors\#48000. Diakses pada tanggal 5 Februari 2014.

Geyer, W.R., P. Hill, T. Millingan dan P. Traykovski. 2000. The study of the eel river plume during floods. Continentalal shelf research 20(16): 2067-2093.

Kalangi, P.N.I. 2008. Struktur salinitas di perairan pantai muara Sungai Sario Manado. Pacific Journal 3(2): 195199.

Kalangi, P.N.I., K.W.A. Masengi, M. Iwata, F.P.T. Pangalila dan I.F. Mandagi. 2012. Profil salinitas dan suhu di Teluk Manado pada hari-hari hujan dan tidak hujan. Jurnal Perikanan dan Kelautan Tropis VIII(3): 90-93.

Kamat, Y.N., P.N.I. Kalangi dan M.S. Sompie. 2014. Pola arus permukaan saat surut di sekitar muara Sungai Malalayang, Teluk Manado. Jurnal Ilmu dan Teknologi Perikanan Tangkap 1(Edisi Khusus November): 99-104.

Neumann, G. dan J. W. Pierson. 1966. Principle of Physical Oceanography. Prentice Hall, Englewood Cliffs, England.

Odum, E.P. 1971. Fundamental of Ecology. Third Edition WB Saunder Company. Philadelphia, London.

Rampengan, R.M. 2009. Pengaruh pasang surut pada pergerakan arus permukaan di Teluk Manado. Jurnal Perikanan dan Kelauan V(3): 15-19.

Supriadi, I.H. 2001. Dinamika estuaria tropik. Oseana XXVI(4): 1-11.

Supriharyono. 2000. Pelestarian dan Pengelolaan Sumberdaya Alam di Wilayah Pesisir Tropis. Gramedia Pustaka Utama, Jakarta. 